\title{
Cyclic oxidation resistance of hot-dipping Al-5Si coating on $0 \mathrm{Cr} 18 \mathrm{Ni10Ti}$
}

\author{
Bi-lin Shao ${ }^{1}$, Jin Lou ${ }^{2}$, Cheng-xiang Ruan ${ }^{2}, \mathrm{Zuo} \mathrm{Yi}^{2}$ \\ ${ }^{1}$ Academic Affair office, Jiangxi Science and Technology Normal University, Nanchang, Jiangxi, \\ China \\ ${ }^{2}$ School of Material and Machinery Engineering, Jiangxi Science and Technology Normal \\ University, Nanchang, Jiangxi, China
}

Keywords: cyclic oxidation resistance; hot-dipping Al-Si; high temperature oxidation; 0Cr18Ni10Ti

\begin{abstract}
Cr18Ni10Ti austenitic stainless steels were coated by hot-dipping in molten Al bath and molten Al-5 wt. \% Si bath. The cyclic oxidation resistance behavior of both hot-dipping Al samples and hot-dipping Al-5Si samples at $900^{\circ} \mathrm{C}$ for 24 cycles have been investigated using muffle furnace. The element distribution, phase composition and morphology of the aluminide layer and the oxide film were characterized by SEM and EDS. The results show the coating layers on both hot-dipping Al samples and hot-dipping Al-5Si samples after 24 cycles at $900^{\circ} \mathrm{C}$ consisted of four layers, in the sequence of $\mathrm{A} 12 \mathrm{O} 3$ film, outer layer with black phase and grey phase, intermediate MAl layer, Al solution layer from the external topcoat to substrate. The thickness of intermediate MAl layer of hot-dipping Al-5Si samples was lower than the thickness of MAl layer of hot-dipping Al samples. Some cracks were found on intermediate MAl layer of hot-dipping Al samples after 24 cycles at $900^{\circ} \mathrm{C}$. The cyclic oxidation resistance of Al-5Si samples is better than Al-5Si samples at $900^{\circ} \mathrm{C}$ for $24 \mathrm{~h}$.
\end{abstract}

\section{Introduction}

Hot dipping aluminizing is an effective method to improve the high temperature oxidation resistance due to fine, dense Alminum oxide scale formed on the surface of the coating. The steel was dipped into molten aluminum or molten aluminum alloy and was keeping the appropriate time after preprocessing such as degreasing, descaling and plating. During the dipping process, Fe-Al intermetallic compound was generated due to interdiffusion between Fe from steels and $\mathrm{Al}$ of the molten aluminum. The Fe-Al intermetallic compound resulted in metallurgical bonding between the $\mathrm{Al}$ coating and steels, which resulted in the coating difficult to fall off [1]. After diffusion annealing, the thickness of $\mathrm{Fe}-\mathrm{Al}$ intermetalic compound layer was increased, and then the high temperature oxidation resistance of hot dipped coating on steel was increased [2-4]. The intermetallic compound was brittle phase. Therefore, the increased thick of intermetallic compound layer wound lead to generate crackles in Al coating. Then, Oxygen passed through Al coating to react with alloy atoms of steel, which means the high temperature oxidation resistance of hot dipping coating was decreased [5-6]. It was reported that the thickness of intermetallic compound layer was decreased with addition silicon in the melt and then Fe-Al-Si compound layer was formed on carbon steel [7-8]. Wang has studied the isothermal and cyclic oxidation of mild steel with Al-2.5Si, Al-5Si, Al-10Si at 750. The results of the cyclic oxidation showed that the steel with Al-5Si had the best cyclic oxidation resistance during Al-2.5Si, Al-5Si, Al-10Si [9]. Therefore, in order to increase the cyclic oxidation of $0 \mathrm{Cr} 18 \mathrm{Ni10 \textrm {Ti }}$ austenitic stainless steel, coating was formed on stainless steel by hot dipping Aluminum with addition $5 \mathrm{wt} \% \mathrm{Si}$. To study the effect of Si in Al-Si coating, the cyclic oxidation resistance of hot dipping $\mathrm{Al}$ and hot dipping Al-5Si on 0Cr18Ni10 Ti was researched at $900^{\circ} \mathrm{C}$ and the influence of $\mathrm{Cr}, \mathrm{Ni}$, atoms of $0 \mathrm{Cr} 18 \mathrm{Ni} 10 \mathrm{Ti}$ steel on the cyclic oxidation resistance was studied. 


\section{Experiment procedures}

\section{Materials.}

The chemical composition of 0Cr18Ni10Ti austenitic stainless steel is given in table1.

Table1 Chemical composition of 0Cr18Ni10Ti austenitic stainless steel (mass, wt \%)

\begin{tabular}{lllllllll}
$\mathrm{C}$ & $\mathrm{Si}$ & $\mathrm{Mn}$ & $\mathrm{S}$ & $\mathrm{P}$ & $\mathrm{Cr}$ & $\mathrm{Ni}$ & $\mathrm{Ti}$ & $\mathrm{Fe}$ \\
\hline$\leq 0.08$ & $\leq$ & $\leq 2$ & $\leq 0.03$ & $\leq$ & $17-1$ & $9-1$ & $\leq 0$. & Bal. \\
& 1 & & & 0.035 & 9 & 2 & 4 &
\end{tabular}

Specimens were cut to $\Phi 1 \mathrm{~cm} \times 0.17 \mathrm{~cm}$ by water-cooled cutting machine, and had a hole drilled $0.8 \mathrm{~mm}$ in diameter. Specimens were ground to $2000^{\#}$ sic paper and polished.

Commercial grade pure aluminum with a purity of $99.97 \%$ and Commercial grade pure Silicon with a purity of $99.7 \%$ were used as the molten alloy bath. The aluminum ingots and the silicon ingots were heated to $700{ }^{\circ} \mathrm{C}$ in a graphite crucible using a resistance furnace SG-5-12, and keep 7 days. The $0 \mathrm{Cr} 18 \mathrm{Ni10Ti}$ samples were degrease at $85{ }^{\circ} \mathrm{C}$ for $15 \mathrm{~min}$, rinsed with hot water, and then descaled in $15 \% \mathrm{HCl}$ at $30{ }^{\circ} \mathrm{C}$ for $8 \mathrm{~min}$, rinsed with hot water again, and then promoted in a molten salt mixture at $90{ }^{\circ} \mathrm{C}$ for $2 \mathrm{~min}$. After being surface-preheated at $270{ }^{\circ} \mathrm{C}$, the steel specimens were immersed in the pure aluminum, Al-5Si(wt\%) molten baths at $800{ }^{\circ} \mathrm{C}$ for $2 \mathrm{~min}$ and then cooled in water. After aluminizing, the specimens were diffused in resistance furnace at $950^{\circ} \mathrm{C}$ for $2 \mathrm{~h}$ and were cooled inside furnace to room temperature. The outer rough surfaces of aluminized samples were removed to improve the oxidation resistance using steel file [5, 10]. Hereafter, the hot dipping Al samples were termed HDA samples and the hot dipping Al-5Si samples were termed HDA5Si samples.

\section{Cyclic-Oxidation.}

Cyclic oxidations of HDA samples and HDA5Si samples were conducted at $900{ }^{\circ} \mathrm{C}$ in static air for 24 cycles. Each sample was putted in corundum crucible. Then, the crucibles with samples were placed in muffle furnace. Each cycle consisted of oxidation for $50 \mathrm{~min}$ in the furnace followed by 10 min outside the furnace to room temperature. The weight changes of specimens after cyclic oxidation were measured together with crucibles by electronic balance $(0.1 \mathrm{mg}$ accuracy).

\section{Analysis Method.}

The surface morphology and cross-section of oxidized specimens were examined by scanning-electron microscopy (SEM) with energy-dispersive spectrometry (EDS). Surface morphologies were observed by SEM in secondary electron mode (SE2). The samples after cyclic oxidation were prepared for cross-sectional observation using standard grinding and polishing. Cross-section specimens were observed by SEM in black scattered electron mode (BSE). Chemical compositions of the phase observed from SEM were analyzed by EDS. Phase on oxidized samples was identified by-ray diffraction (XRD).

\section{Result and discussion}

\section{Oxidation kinetics.}

Mass-gain as a function of the number of $1-\mathrm{hr}$ cycles at $900^{\circ} \mathrm{C}$ was presented in figure.1. As shown in figure.1, the oxidation mass gain of HDA samples and HDA5Si samples were unstable at the initial stage, and then both HDA samples and HDA5Si samples retained a relatively stable value at a later stage. This means that dense and protective $\mathrm{Al}_{2} \mathrm{O}_{3}$ films were formed on both HDA samples and HDA5Si samples at the later stage. Mass gain value of HDA samples at 24 cycles was $0.727 \mathrm{mg} / \mathrm{cm}^{2}$, while Mass gain value of HDA5Si samples at 24 cycles was lower with 0.0786 $\mathrm{mg} / \mathrm{cm}^{2}$. The lower mass gain might due to denser oxide $\mathrm{Al}_{2} \mathrm{O}_{3}$ scale was formed on HDA5Si samples. 


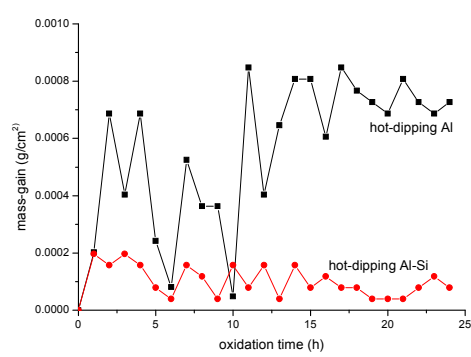

Figure. 1 The cyclic oxidation kinetics of hot-dipping aluminum and $\mathrm{GH} 169$ at $900{ }^{\circ} \mathrm{C}$ for 24 cycles

\section{Surface and Cross-section morphology.}

$\mathrm{X}$-ray diffraction analysis revealed that $\mathrm{Al}_{2} \mathrm{O}_{3}$ oxide scales were formed on HDA samples and HDA5Si samples after 24 cycles at $900^{\circ} \mathrm{C}$. Observations of the top surface of the scale shown that the $\mathrm{Al}_{2} \mathrm{O}_{3}$ oxide scale on HDA samples (figure. $2(\mathrm{a}, \mathrm{b})$ ) after 24 cycles was irregularity with little white oxides included in the oxide scale (figure2 (a)). The white oxides on HDA samples was analysis by EDS, which was composed of O 80.95 at $\%$, Ti 14.04 at $\%$, Al 4.70 at $\%$, Fe 0.32 at $\%$. This means the white oxide is mainly the oxide of $\mathrm{Ti}$, so the white oxide in $\mathrm{Al}_{2} \mathrm{O}_{3}$ oxide film is $\mathrm{TiO}_{2}$. $\mathrm{TiO}_{2}$ distributed in $\mathrm{Al}_{2} \mathrm{O}_{3}$ oxide scale might destroyed the continuity of oxide scale [11]. The $\mathrm{Al}_{2} \mathrm{O}_{3}$ oxide scale on HDA5Si samples in figure.2(c) after 24 cycles was smoother and denser than the $\mathrm{Al}_{2} \mathrm{O}_{3}$ oxide scale on HDA. There are some white oxides scattered on $\mathrm{Al}_{2} \mathrm{O}_{3}$ oxide scale of $\mathrm{HDA} 5 \mathrm{Si}$ samples in figure2(c). EDS analysis illustrate the white phases on HDA5Si samples consisted of Fe oxide and Ti oxide. The denser oxide scale samples was consistent with lower weight gain on HDA5Si after 24 cycles at $900^{\circ} \mathrm{C}$.
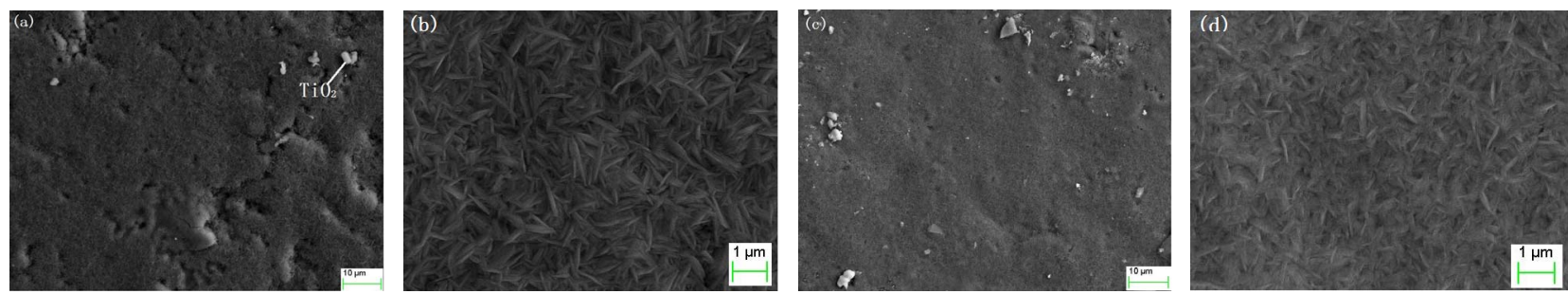

Figure.2 The morphology of surface hot dipping Al samples and hot dipping Al-5Si samples after cyclic oxidation at $900^{\circ} \mathrm{C}$ for 24 cycles (a) (b)hot dipping $\mathrm{Al}$ (c)(d) hot dipping Al-5Si

Observation of the cross-section morphology of HDA samples (figure 3(a)) and HDA5Si samples (figure $3(\mathrm{c})$ ) after 24 cycles at $900^{\circ} \mathrm{C}$ shown that similar microstructure was formed: $\mathrm{Al}_{2} \mathrm{O}_{3}$ oxide film, outer layer, intermediate layer and inner layer. The outer layer composed of black phase and gray phase. Element analysis revealed that the alloy atom content was different as shown in table 2.The line scan analysis of HDA samples and HDA5Si samples by EDS were shown in figure 3 (b) and figure3 (d), respectively. Observation of figure3 (b) and figure3 (d) shown that the $\mathrm{Al}$ distribution in outer layer was rugged due to the different $\mathrm{Al}$ content in black phase and grey phase. The Al content of intermediate was uniform and the Al content in inner layer was gradually reduced. 

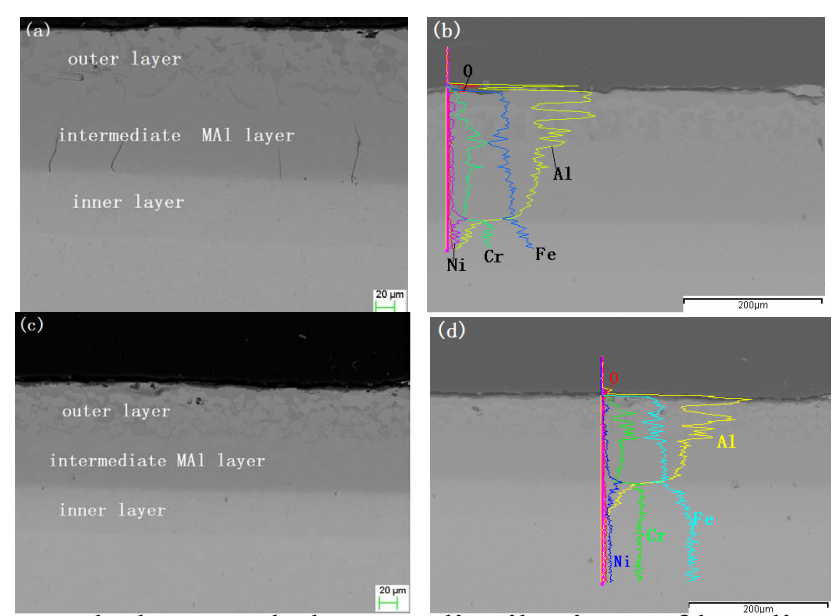

Figure. 3 cross-section morphology and element distributions of hot dipping Al samples and hot dipping Al-5Si samples after cyclic oxidation at $900^{\circ} \mathrm{C}$ for 24 cycles (a) (b)hot dipping $\mathrm{Al}$ (c)(d) hot dipping Al-5Si

As shown in table 2, Al content of black phase is higher than $\mathrm{Al}$ content of grey phase in outer layer; the component of grey phase of outer layer was similar to the component of intermediate layer. This means Al diffused into matrix during oxidation process and the black phase wound transformed to gray phase. Then the outer layer wound disappeared with increasing time. According to $\mathrm{Al}$ atomic ratio of metal atoms, the intermediate layer was composed of $\mathrm{MAl}$ ( $\mathrm{M}$ on behalf of $\mathrm{Fe}$, $\mathrm{Cr}, \mathrm{Ni}$ et al). The $\mathrm{Al}$ content gradually reduce in inner layer revealed that $\mathrm{Al}$ diffused into matrix gradually and $\mathrm{Al}$ dissolute in steel. So, the inner layer was called Al solution $\mathrm{Fe}(\mathrm{Al})$ layer. The distribution of $\mathrm{Fe}$ and $\mathrm{Cr}$ atom of steel gradually reduce from matrix to outer layer in Table 2. This distribution means the alloy atoms diffused outward.

Table 2 Chemical compositional of coating on hot dipping $\mathrm{Al}$ samples and hot dipping Al-5Si samples

\begin{tabular}{|c|c|c|c|c|c|c|}
\hline & sample & & $\mathrm{Al}($ at $\%)$ & $\begin{array}{c}\mathrm{Cr} \\
\text { (at \%) }\end{array}$ & $\mathrm{Fe}($ at $\%)$ & $\mathrm{Ni}($ at $\%)$ \\
\hline \multirow{4}{*}{ HDA samples } & \multirow{2}{*}{$\begin{array}{l}\text { Outer } \\
\text { layer }\end{array}$} & $\begin{array}{l}\text { Black } \\
\text { phase }\end{array}$ & 66.07 & 3.57 & 28.67 & 1.18 \\
\hline & & $\begin{array}{l}\text { Grey } \\
\text { phase }\end{array}$ & 52.00 & 7.74 & 32.73 & 6.05 \\
\hline & \multicolumn{2}{|c|}{ Intermediate layer } & 50.78 & 8.40 & 34.56 & 4.88 \\
\hline & \multicolumn{2}{|c|}{ Inner layer } & 14.24 & 19.56 & 54.40 & 0.53 \\
\hline \multirow{4}{*}{$\begin{array}{l}\text { HDA5Si } \\
\text { samples }\end{array}$} & \multirow{2}{*}{$\begin{array}{l}\text { Outer } \\
\text { layer }\end{array}$} & $\begin{array}{l}\text { Black } \\
\text { phase }\end{array}$ & 64.48 & 3.74 & 30.42 & 1.00 \\
\hline & & $\begin{array}{l}\text { Grey } \\
\text { phase }\end{array}$ & 51.24 & 8.09 & 35.17 & 4.69 \\
\hline & \multicolumn{2}{|c|}{ Intermediate layer } & 50.04 & 8.47 & 35.66 & 4.41 \\
\hline & \multicolumn{2}{|c|}{ Inner layer } & 13.19 & 20.39 & 55.59 & 7.68 \\
\hline
\end{tabular}

The formation of intermediate layer was due to interdiffusion of $\mathrm{Al}$ and alloy atoms of steel. With increasing time, the thickness was increased. Compare figureure 3 (a) and figureure3 (c), the thickness of intermediate layer of HDA samples (figure3 (a)) was more than the intermediate layer of HDA5Si samples (figure3 (c)). And some cracks were found in intermediate layer of HDA samples, because of different coefficient of thermal expansion of steel and MAl layer. The thin intermediate layer on HDA sample due to silicon in the moleten aluminum helps in reducing the thickness of MAl layer $[12,13]$.

According to Wang' study on hot dipping Al-Si coating on mild steels, voids were found at the 
interface between the compound layer and the steel substrate and the study point out that voids were formed due to kirkendall effect. In this work, No voids were formed between the MAl compound layer and inner solid solution layer in HDA samples and HDA5Si samples. It might be that during oxidation $\mathrm{Fe}, \mathrm{Cr}$, Ni diffused outward in HDA samples and HDA samples and the $\mathrm{Cr}$, Ni reduces the diffusion rate of $\mathrm{Fe}$.

\section{Conclusions}

1) During cyclic oxidation process at $900{ }^{\circ} \mathrm{C}$, mass-gains of hot dipping Al-5Si samples and hot-dipping aluminum were unstable at the early stage, and then retained a relative stable value due to formation protective $\mathrm{Al}_{2} \mathrm{O}_{3}$ scales. After2 4 cycles, mass-gains of hot dipping Al-5Si samples was lower than mass-gain of hot dipping Al samples resulting from denser oxide scale on hot dipping Al-5Si samples.

2) After 24 cycles at $900{ }^{\circ} \mathrm{C}$, Similar microstructures were formed on hot dipping Al-5Si samples and hot dipping $\mathrm{Al}$ samples: $\mathrm{Al}_{2} \mathrm{O}_{3}$ film, outer layer conclude black phase and grey phase, intermediate MAl layer and inner solid solution $\mathrm{Fe}(\mathrm{Al})$ layer. The thickness of MAl layer on hot dipping Al-5Si samples was lower than hot dipping Al because of silicon in the molten aluminum helps in reducing the thickness of MAl layer.

3) The cyclic oxidation resistance of Al-5Si samples is better than Al-5Si samples at $900^{\circ} \mathrm{C}$ for $24 \mathrm{~h}$.

\section{Acknowledgement}

We are grateful to the financial support of the Natural Science Foundation (No. 51363008).

\section{References}

[1] H.L.Li ,G.X.Li, Y.R.Zheng, et al. Journal of Material and Metallurgy, 3(2004):52-53.

[2] W.Sun, QZ.Cai, Q.Luo. Transactions of materials and heat treatment, 32(2011):114-120

[3] J.JIA, W.W. ZHU, W.XIONG, et al. Transactions of Materials and Heat Treatment, 35(2014):205-209.

[4] Y.L.Liao, S.Q.Wang, Q.Y.Zhang, L. Wang, Iron Steel Vanadium Titanium, 34(2013).

[5] S.W.Yang, L.Li, Zh.H.Luo, Corrosion and Protection, 21(2000):64-66.

[6] S.X.Yu, Y.Xia, M.Yao, Rare Metal Materials and engineering, 35(2006):74-78.

[7] G.H. Awan, F. Hasan. Materials Science and Engineering A 472 (2008) 157-165

[8] EI-Mallhallawy Na,TahaMA,ShadyM A ,et al. Material Science Technology, 13(1997):832-840.

[9] W.J.Cheng, C.J.Wang. Applied Surfac Science, 274(2013):258-265.

[10]J. Lou, J.K.Wang, Y.B.Wang. Hot Working Technology, 22(2014)

[11] J.Angenete, K.Stilller, V.langer. Oxidation of Metal, 60(2003):47-64.

[12] M.V.Akdeniz, A.O.Mekhrabov,T.Yilmaz, Scripta Mtall.Maer.3(1994)1723

[13] S.Kobayashi, T.Yakou, Mater. Sci. Eng. A338(2002): 44 